www.jmscr.igmpublication.org

Index Copernicus Value: 79.54

ISSN (e)-2347-176x ISSN (p) 2455-0450

crossrefDOI: https://dx.doi.org/10.18535/jmscr/v7i2.24

\title{
Diagnostic Utility of PCR in Sputum of Patients with Pulmonary Tuberculosis
}

Authors

\section{Dr Ankit Mehrotra ${ }^{1}$ Dr Shiv Sagar Gupta ${ }^{2}$, Dr Avinash Kumar ${ }^{3}$, Dr Santosh Kumar ${ }^{4}$, Dr Rishabh Goyal ${ }^{5}$, Dr Sanjeev Anand ${ }^{6 *}$}

${ }^{1}$ Assistant Professor Deptt. of Pulmonary Medicine Varun arjun Medical College Shahjahanpur

${ }^{2}$ Ex. Assistant Professor Deptt. of TB \& Chest Diseases Era's Lucknow Medical College Lucknow

${ }^{3}$ Junior Resident Deptt. of TB \& Chest Diseases S.N. Medical College Agra

${ }^{4}$ Professor \& Head TB \& Chest Diseases S.N. Medical College Agra

${ }^{5}$ Senior Resident Deptt. of TB \& Chest Diseases S.N. Medical College Agra

${ }^{6}$ Assistant Professor Deptt. of TB \& Chest Diseases F.H. Medical College, Tundla, Firozabad

*Corresponding Author

Dr Sanjeev Anand

Assistant Professor Deptt. of TB \& Chest Diseases F.H. Medical College, Tundla, Firozabad Add: C/o Dr. Santosh Kumar Head of the department, Deptt. of TB \& Chest Diseases, S.N. Medical College Agra. 282002, India

Phone No- 9897517869 Email: skumardr2007@ rediffmail.com

\begin{abstract}
Aims and Objectives: To find out the diagnostic utility of PCR in sputum of patients with pulmonary tuberculosis.

Material and Methods: We have studied 105 cases and investigated for AFB in their sputum by microscopy after ZN staining and PCR in our department of TB and Respiratory Diseases, Era's lucknow Medical College, Lucknow.

Observation: It was observed that out of 65 clinically suspected cases of pulmonary tuberculosis, 40 were smear (+)ve and 54 were (+)ve by PCR. Sensitivity and specificity of sputum microscopy was $61.5 \%$ and $100 \%$ respectively. Sensitivity and specificity of PCR was $83 \%$ and $100 \%$ respectively.

Conclusion: our study suggests that the diagnosis of pulmonary TB at molecular level (PCR) for detecting mycobacterium tuberculosis, is a rapid and more effective method than microscopic examination.
\end{abstract}

\section{Introduction}

Tuberculosis is caused by bacteria (mycobacterium tuberculosis) that most often affects lungs. Tuberculosis occurs in every part of the world. Tuberculosis is one of the top ten causes of death worldwide. In 2017, 10 million people fell ill with TB, and 1.6 million died from the disease (including 0.3 million among people with HIV). With the pandemic of AIDS and emergence of drug resistant strains of mycobacterium tuberculosis, pulmonary tuberculosis has now become a major health problem to the world community. 
TB spreads from person to person through air when person with pulmonary TB, coughs, sneeze or spits they propel the bacteria and inhalation of these bacteria can cause TB infection.

So early and rapid diagnosis and treatment of the case is the most important step in reducing the TB incidence.

Global incidence is falling at about $2 \%$ per year. This needs to accelerate to a $4-5 \%$ annual decline to reach the 2020 milestones of the End TB strategy.

Lab diagnosis of $\mathrm{TB}$ is based on traditional method of smear microscopy by Ziel-neelsen staining and on sputum culture of Mycobacterium Tuberculosis. Sputum microscopy is rapid and inexpensive but bacterial concentration required is 10,000 Acid Fast Bacillii per ml or greater. It also lacks specificity and cannot distinguish various strains of mycobacterium. Culture of Mycobacterium tuberculosis is more sensitive and 10-100 viable bacilli are required but it takes long period to produce results.

The detection of Mycobacterium Tuberculosis by Polymerase Chain Reaction has been found to be useful in diagnosis of pulmonary tuberculosis.

In our study we have compared this PCR method of detection of mycobacterium to diagnose tuberculosis, with AFB smear staining method.

\section{Material and Method}

This was a hospital based comparative study, conducted in TB and chest Department of Era's Lucknow Medical college, Lucknow.

We have investigated all active and presumptive pulmonary TB cases having clinical, radiological or bacteriological evidence of pulmonary TB. Detailed clinical history was taken and chest $\mathrm{x}$-ray \& sputum smear microscopy after $\mathrm{ZN}$ staining were done.
105 sputum specimens from 105 patients were studied which included 65 specimens from active TB and presumptive TB patients and 40 control specimens from patients of non mycobacterial respiratory diseases.

Three early morning sample of sputum brought up by deep productive cough were collected in sterile disposable container for three days before breakfast having mucopurulent sputum.

Sputum microscopy was done after preparing a sputum smear on grease free glass slide and acid fast staining by Ziehl-Neelsen staining method. Every slide was first examined under $45 \mathrm{X}$ and then under oil emersion 100X of microscope.

AFB appears as pink rod in a contrasting blue background.

PCR was done after DNA extraction. The amplification was carried out with an initial denaturation step at $95^{\circ} \mathrm{C}$ for 5 minutes followed by 35 cycles of $95^{\circ} \mathrm{C}$ for 1 minutes, $55^{\circ} \mathrm{C}$ for 1 minute, $72^{\circ} \mathrm{C}$ for 1 minute and a final extension at $72^{\circ} \mathrm{C}$ for $\mathrm{t} 10$ minutes.

Primer used for amplification was IS6110(123bp) designed for specific amplification of conserved sequences of mycobacterium Tuberculosis having sequence (F) 5'-CCTGCGAGCGTAGGCGTCGG-3' (R)5'-CTCGTCCAGCGCCGCTTCGG-3'.

$5 \mu 1$ of PCR products of sample were loaded along with molecular weight marker on $2 \%$ argose gel stained with ethedium bromide and viewed with UV transilluminator. The amplification was checked for $123 \mathrm{bp}$ fragments.

\section{Observation}

The present study was conducted on 105 patients aged more than $12 \mathrm{yr}$, out of which 65 patients were clinically diagnosed as pulmonary TB and 40 patients were control, attending outpatient department of TB and Respiratory Diseases, Era's Lucknow Medical College, Lucknow.

\begin{tabular}{|l|c|c|c|c|c|}
\hline Group & \multirow{2}{*}{ Total } & \multicolumn{2}{|c|}{ Sputum Microscopy } & \multicolumn{2}{|c|}{ PCR } \\
\cline { 3 - 6 } & & $(+) \mathrm{ve}$ & $(-) \mathrm{ve}$ & $(+) \mathrm{ve}$ & $(-) \mathrm{ve}$ \\
\hline Pul. TB & 65 & 40 & 25 & 54 & 11 \\
\hline Non mycobacterial respiratory disease & 40 & 0 & 40 & 0 & 40 \\
\hline
\end{tabular}


It was observed that out of out of 65 clinically were smear (+)ve and 54 were (+)ve by PCR. suspected cases of pulmonary tuberculosis, 40

\begin{tabular}{|l|c|c|c|}
\hline Sputum Microscopy & No. of cases & Control & Total \\
\hline Positive & 40 (True positive) & 0 (False positive) & 40 \\
\hline Negative & 25 (False negative) & 40 (True negative) & 65 \\
\hline Total & 65 & 40 & 105 \\
\hline
\end{tabular}

$$
\begin{array}{llll}
\text { Sensitivity } & =40 / 65=61.5 \% & (+) \text { ve Predictive Value } & =40 / 40=100 \% \\
\text { Specificity } & =40 / 40=100 \% & (-) \text { ve predictive Value } & =40 / 65=61.5 \%
\end{array}
$$

\begin{tabular}{|l|c|c|c|}
\hline PCR & No. of cases & Control & Total \\
\hline Positive & 54 (True positive) & 0 (False positive) & 54 \\
\hline Negative & 11 (False negative) & 40 (True negative) & 51 \\
\hline Total & 65 & 40 & 105 \\
\hline
\end{tabular}

$$
\begin{array}{lccc}
\text { Sensitivity } & =54 / 65=83.0 \% & (+) \text { ve Predictive Value } & =54 / 54=100 \% \\
\text { Specificity } & =40 / 40=100 \% & \text { (-)ve predictive Value } & =40 / 51=78.3 \%
\end{array}
$$

\section{Discussion}

Among the specimens from patient with pulmonary tuberculosis, the detection rate of PCR (83\%) was found to be far better than microscopic examination of smear $(61.5 \%) \quad \mathrm{P}<0.001$ for detecting mycobacterium tuberculosis. In our study detection rate of PCR (83\%) is comparable to those reported by yuen k.y. et al 1993) $80 \%$, yoon k.h.et al (1992) 80.7\%. In our study sensitivity of smear microscopy was $61.5 \%$ is comparable to sevic b. et al (1992) $66 \%$ and higher than those reported by zhuang et al (1994) $23.5 \%$.

Out of 25 smear negative specimens, collected from patients with pulmonary tuberculosis, 14 (56\%) were detected by PCR which is comparable to nolte et al (1993) $57.6 \%$.

There was no false positive result detected by PCR in our study consisting of control group of 40, which is comparable to study by zhuang y.h. et al (1993) reporting no false positive PCR results.

\section{Conclusion}

The study suggests that the diagnosis of pulmonary $\mathrm{TB}$ at molecular level (PCR) for detecting mycobacterium tuberculosis, is a rapid and more effective method than microscopic examination. 